\title{
«SOLI HISPANI»? INNOCENT III AND LAS NAVAS DE TOLOSA
}

\author{
POR
}

DAMIAN J. SMTTH

University of Birminghan

\section{RESUMEN}

El autor analiza en este artículo el influjo del Papa Inocencio III en la consecución de la visctoria cristiana en la batalla de Las Navas de Tolosa y la proyección que tomó en España en las ideas de batalla y reconquista. Los elementos esenciales fueron: reforma de la Iglesia, el estableciemiento de la Paz y la propagación del cristianismo.

\begin{abstract}
Then study here exposed tries to understand the pope of Innocent III in the battle of Las Navas de Tolosa and it influence in Spain through the notins of crusade and Reconquista. The esential elements were: the reform of the Church, the establishmnet of peace and the spiritual propagation of Christendon.
\end{abstract}

\section{RODRIGO JIMÉNEZ DE RADA AND INNOCENT III}

Though one might expect that education in the theology and philosophy of the Paris schools and in the Canon Law of Bologna might have bound them together, as a shared intellectual inheritance bound many others to the Pope, the archbishop of Toledo, Rodrigo Jiménez de Rada (1208-1247), exceptional 
author, politician, propagator of the Reconquista and of Toledan primacy, did not recall Innocent III (1198-1216) with any measurable degree of affection'.

In Rodrigo's most celebrated and influential work. De Rebus Hispanie, the draft of which was completed in $1243^{2}$, twenty-seven years after the death of Innocent, Rodrigo directly mentioned Innocent on four occasions and concerning three subjects; subjects that were close to the Archbishop's heart - the primacy, money, and the Reconquista - and certainly on three of these occasions, Innocent is connected with events which held unhappy memories for Rodrigo:

1) Book VI, chapter 4: Rodrigo recalls that Innocent had crowned King Peter II of Aragon at the monastery of San Pancrazio. This puzzling event of 10 November 1204 held gloomy implications for Rodrigo's cherished Toledan primacy (the primatial rights Toledo claimed over the Braga, Compostela, Narbonne and Tarragona metropolitans) since, on 16 June 1205, Innocent ordered all subsequent Aragonese coronations to be performed by the archbishop of Tarragona (implicitly an equal to Rodrigo as metropolitan and at Zaragoza (a potential rival capital to Toledo) ${ }^{3}$.

I 1. On Pope Innocent III's education, M. MACCARRONE, «Innocenzo III prima del pontificato»: ASRSP 66 (1943) 70-81., J. C. MOORE, «Lotario dei Conti di Segni (Pope Innocent III) in the 1180s»: AHP 29 (1991) 255 8; K. PENNINGTON, «The Legal Education of Pope Innocent III»: Bulletin of the Institute of Medieval Canon Law 4 (1974) 70-7; DEM, «Further thoughts on Pope Innocent III's knowledge of law»: Zeitschrift für Rechtsgeschichte 113 (1986) 417-28; W. IMKAMP, Das Kirchenbild Innocenz'HI (1198-1216), Stuttgart 1983, 20-45. On Rodrigo's education, M. BALLESTEROS GAIBROIS, Don Rodrigo Jiménez de Rada, Barcelona 1936, 34-5, 44; H. GRASSOTTI, «Don Rodrigo Ximénez de Rada, gran seffor y hombre de negocios en la Castilla del siglo XIII: Cuadernos de Historia de España 55-6 (1972) 4; A. CASTRO, La Realidad Histórica de España, México 1954, 209-10. Rodrigo was still in Paris in April 1201 when he made his will promising to be buried at the monastery of Huerta (Cartulario del monasterio de Santa Marta de Huerta, ed. J. A. GARCIA LUJÁN, Monasterio de Santa Maria de Huerta 1981, no. 71, p. 113). On the educational friendship network of Innocent III. J.W. BALDWIN, Masters, Princes and Merchants., the Social Views of Peter the Chanter and his Circle, 2 vols, Princeton 1970; T. NIELSEN, «Vicarius Christi, Plenitudo potestatis og causae maiores: Teologi og Jura hos Pave Innocens.III (1198-1216) og Aerkebiskop Anders Sunesen (12011223)»: Historisk Tidsskrift 94 (1994)1-29.

${ }^{2}$ RODRIGO XIMÉNEZ DE RADA, Historia de rebvs Hispanie sive Historia Gothica, ed. J. FERNANDEZ VALVERDE, CCCM 72 (1987)[hereafter DRH] xvi xix. On the dates of composition, $B$. F. REILLY, «Sources of the Fourth Book of Lucas of Tuy's Chronicon Mundi»: Classical Folia 30 (1976) 131-2; P. LINEHAN, History and the Historians of Medieval Spain, Oxford 1993, 350-1. On the value of Rodrigo as a historian, D. LOMAX, «Rodrigo Jiménez de Rada como historiador»: Actas del Quinto Congreso Internacional de Hispanistas, Bordeaux 1977, 589.

${ }^{3}$ DRH, Bk. VI, c. 4, p. 181; La documentación pontificia hasta Inocencio III (965-1216), ed. D. MANSILLA, Rome 1955 [hereafter MDHI], no. 307, pp. 339 41, no. 314, pp. 346-7; Regesta pontificum Romanorum inde ab anno 1198 ad annum 1304, ed. A. POTTHAST, 2 vols, Graz 1957 [volume 1, bereafter Potthast], 2322, 2361, 2543; Patrologiae latinae cursus completos, ed. J.-P. MiGNE, 221

Proyección internacional de la iglesia hispana Hispania Sacra 51 (1999) 
2) Book VII, chapter 24: Rodrigo fumes because the Pope's intransigent insistence on the sacramentality of marriage had broken the incestuous marriage of Alfonso IX of León (1188-1230) and the infanta Berenguela, daughter of Alfonso VIII of Castile (1158-1214) and therefore, from Rodrigo's viewpoint, Innocent had scuppered the chances of peace between León and Castile and thus Innocent had halted the process of the Reconquista ${ }^{4}$.

3) Book IX, chapter 2: Rodrigo merely mentions that Innocent had prohibited the marriage of King Henry I of Castile (1214-1217) to the infanta Mafalda of Portugal. Innocent's letter of 1216 escapes direct censure and while Rodrigo might expect us to recall the result of Innocent's previous marital interference, the abandonment of this projected incestuous union, did not assume the same political importance, both because the situation against the Moors was no longer parlous and Henry's life was soon to be over ${ }^{5}$.

4) Book IX, chapter 9: Rodrigo recollects that Master Gonzalo García, the papal tax-collector in the Iberian Peninsula between 1213 and 1222, had been of the household of Innocent III. Gonzalo it was who had uncovered Rodrigo's misappropriation of the revenue raised from the crusading tax and hence earned the Archbishop the censure of Honorius III in 1220 and a demand for full payment of the sames.

Innocent III had plenty of detractors. From Walter von der Vogelweide's mild ' $\mathrm{Oh}$, the Pope is too young. God, help your Christendom' to Giovanni Capocci's reported accusation 'Your words are God's words, but your works

vols, Paris 1844-64 [hereafter MPLI, 215, cols. 550, 665; B. PALACIOS MARTIN, La coronación de los reyes de Aragón 1204-1410: Aportación al estudio de las estructuras medievales, Valencia 1975, 102-5; LINEHAN, History and the Historians, 389-90; D. SMITH, Innocent III and Aragon-Catalonia: Studies on Papal Power, University of Birmingham PH.D Thesis 1997, 36-94.

${ }_{4} D R H$, Bk. VII, c. 24 , p. 247: $M D H I$. no. 138. pp. 168-70, no. 196, pp. 209 15, no. 276, pp. $305-6$, no. 299, p. 332, no. 305, pp. 336-9, no. 331, p. 358; J. GONZÁLEZ, El reino de Castilla en la época de Alfonso VIII, 3 vols, Madrid 1960, 1, 723 5; IDEM, Alfonso IX, 2 vols, Madrid 1944, 1, 95 120; LINEHAN, History and the Historians, 256-9; D. MANSILLA, «Inocencio III y los reinos hispanos): Anthologica Annua 2 (1954) 20-31; J. F. RIVERA REClO, La Iglesia de Toledo en el siglo XII, Rome 1966, 237-41; R. FLETCHER, The Episcopate in the Kingdom of Lebn in the Twelfth Century, Oxford 1978, 210-1.

5 DRH, BK. IX, c. 2, p. 283; $M D H I$, nos. 558, 564, pp. 582-3; La documentación pontificia de Honorio III (1216-1227), ed. D. MANSILLA, Rome 1965 [hereafter MDHI, no. 103, p. 84; GONZÁLEZ, Alfonso VIII, 1, 753; IDEM, Alfonso IX, 1. 163-4.

${ }^{6}$ DRH, Bk. IX, c. 9, p. 290; Bulário portugués. Inocencio III (1198-1216), ed. A. DE JESUS DE Costa and M. A. Fernandes MARQues, Coimbra 1989, no. 199; $M D H$, no. 188, pp. 148-9; P. LINEHAN, The Spanish Church and the Papacy in the Thirteenth Century, Cambridge 1971, 18-9; P. FREEDMAN, «Two letters of Pope Honorius III on the collection of ecclesiastical revenues in Spain»: Römische Historische Mittellungen 32-3 (1990-1) 37-40.

Proyección intemacional de la iglesia hispana Hispania Sacra 51 (1999) 
are the devil's works' examples are easily recalled?. Rodrigo's detraction, however, is of special significance and of a special kind. Why 'of special significance'? Because Rodrigo's De Rebus Hispanie has probably done more to shape how other historiaras, medieval and modern, view his homeland than any other single work. Why 'of a special kind'? Because Rodrigo is a first-rate manipulator of history and he knows omittance is the best way to detract from a person or event. Therefore, Rodrigo omitted from his history referente to the proceedings of the Fourth Lateran Council (November, 1215), where, we know, he had unsuccessfully tried to raise his primacy above an honorific dignity by accusing the see of Braga of being a nest of antipopes (referring to Maurice Burdinus) and implying that Santiago at Compostela was nothing but a tall-tale. ${ }^{8}$. In the most famous book of De Rebus Hispanie, Book Eight, Rodrigo's deservedly oft-cited eye-witness account of the campaign of Las Navas de Tolosa (June-July 1212), a narrativo that was generally accepted by later Hispanic chroniclers, Innocent III receives no mention ${ }^{9}$. Rodrigo remembered

${ }^{7}$ Selected Poems of Walther von der Vogelweide, ed. M. FITZGERALD RICHEY, Oxford 1965, 21. Capocci's outburst can be found in Caesariks Heisterbacensis Monachi ordinis Cisterciensis Dialogus Miraculonam, ed. J. STRANGE, 2 vols, Cologne 1851, 1, 103. For other examples, M.-T. ALVERNY, «Novus regnat Salomon in diebus malis: Une satire contre Innocent III): P. G. SCHMIDT (Ed.), Festschrift Bemhard Bischoff, Stuttgart 1971, 382-90: RALPH OF COGGESHALL, Chronicon Anglicanum, ed. J. STEVENSON, Rolls Series 66 (1875) 130 3; S. KUTTNER, «Universal Pope or Servant of God's Servants: The Canonists, Papal Titles, and Innocent II»: Revue du drolt canonique 32 (1981) 129-31.

8 Sacrorum concillorum nova et amplissima collectio, ed. G. MANSI, 31 vols, Florence $1759-98$, 22, 1071-5; A. GARCIA Y GARCIA, «El Concilio IV Lateranense (1215) y Francia»: AHC 26 (1994) 61-86; J. RIVERA RECIO, «Personajes Hispanos Asistentes en 1215 al IV Concilio de Letran»: Hispania Sacra 4 (1951) 335-42; R. Foreville, Latran I, II. II et Latran IV, Paris 1965, 263-5; IDEM, «L'Iconographie du XIIE Concile Oecuménique: Letran IV (1215)»; Mélanges offerts a René Crozet. Poitiers 1966, 1124-7; LJNEHAN, History and the Historians, 328-31.

9 DRH, BK.VII, chs 1-13, pp. 259-78, provides the almost verbatim text for the account of the Las Navas campaign of the most widely disseminated later Medieval Hispanic chronicle: Primera Crónica General de España, ed. R. MENÉNDEZ PIDAL, Madtid 1955, 684-705 (though A. CASTRO, The Spaniards: an Introduction to their History, California 1971, 15-6 notes the increased nationalistic emphasis of the latter) - DRH (or, at least, its author) also inf orms LUCAS OF TUY, Cronica de España, ed. J. Puyol, Madrid 1926, 412-15; G. CIROT (ed. ), «Une chronique latine inédite des rois de Castille (1236)»: Bulletin Hispanique 14 (1912), 271-4, 353-66; Los Anales Toledanos 1 y 11, ed. J. P. Martin Cleto, Toledo 1993, 172-3; Bernat Desclot, Crónica, ed. M. Coll I Allentorn, Barcelona 1982, 53-7. Desclot magnifies the part played in the battle by the Catalan ruler, King Peter II of Aragon (A. GODDARD ELLJOTT, «The Historian as Artist: Manipulation of History in the Chronicle of Desclot»: Viator 14 (1983), 202) and Rodrigo's account was itself further manipulated for the sake of non Castilian rulers. See, Gesta Comitum Barcinonensium, ed, L. BARRAU DIHIGO and J. MASSO TORRENTS, Barcelona 1925, 52-3; The Chronicle of San Juan de la Peña, ed. and trans. L.H.NeLSON, Pennsylvania 1991, 58-9; CARLOS, PRINCIPE DE VIANA, Crónica de los Reyes de Navarra, ed. J. YANGUAS Y MIRANDA, Pamplona 1971, 115. Eventually many towns and nobles added their military prowess to the account of the battle drawing from J. F. POWERS the observation: "Had all the

Proyección internacional de la iglesia hispana Hispania Sacra 51 (1999) 
Innocent without affection and determined that the Papacy's best efforts would be altogether forgotten.

\section{THE SigNifiCANCE OF LAS NAVAS TO SPAIN}

Las Navas was to be a very Spanish affair. 'Soli Hispani cum paucis ultramontanis' fought at Las Navas, Rodrigo famously declared, echoing the phrase 'Soli Yspani virtute sua obtinuerint imperium' used by the eminent canonist Vincentius Hispanus at about the time of the battle, when reflecting on what a poor show the Germans had made of empire ${ }^{10}$. To be precise there were threevictors at Las Navas - God, the Catholic Faith and Spain. For the influential Bishop Lucas of Tuy, in his much-thumbed Chronicon Mundi, "pugnant Hispani reges pro fide' 11 ; Alfonso VIII later assigned his successinon 'meis meritis sed Dei misericordia et meorum auxilio vassallorum' 12; For Rodrigo, at Las Navas Alfonso VIII fought 'pro fi de Christi mori desiderans'13 and even Sancho VI I of Navarre (1194-1234) turned up, bound 'in fidei catholice'14. The matter was perhaps best summed up by Bishop Juan of Osma in the Chronique latine des rois de Castile: 'Mirabilis Deus in sanctis suis qui tan mirabiliter providit Yspanie et precipue regno Castelle ut recedentibus ultramontanis gloria victorie belli famosi Yspanis non ultramontanis tribueretur' 15 .

Though Rodrigo and his contemporaries recognized the importance of the attempt to internationalize the campaign and were fully conscious of their role in defending Christianitas, the participation of Rome was perceived as at best negligible, her success amounting to securing by Indulgences the ephemeral support of the treacherous Franci who had fled before the battle ${ }^{16}$. As percepti-

municipal claimants produced their alleged forces along with the myriad aristocratic ancestors who allegedly participated in the battle, the support column might well have extended back to Santander'(J. F. POWERS, A Society Organized for War: The Iberian Municipal Militias in the Central Middle Ages, 1000-1284, California 1988, 53); A. HUICI MIRANDA, Las Grandes Batallas de la Reconquista durante las Invasiones Africanas, Madrid 1956, 255-7, provides lists of actual and alleged participants.

${ }^{10}$ DRH, BK.VII, c. 6, p. 266; G. POST, «'Blessed Lady Spain' Vincentius Hispanus and Spanish National Imperialism in the Thirteenth Centurys: Speculum 29 (1954) 206.

"I LUCAS OF TUY, Crónica de España, 413.

12 F. FITA, "Testamento del Rey D. Alfonso VII (8 Diciembre 1204)»: Boletín de la Real Academia de la Historia 8 (1886) 241.

${ }^{13}$ DRH, BK.VII, c. 34, p. 256.

${ }^{14} \mathrm{MDHI}$, no. 483, p. 510.

15 G. CIROT (ed. ), «Chronique latine», 357-8; D. LOMAX, «The authorship of the Chronique latine des rois de Castilen; Bulletin of Hispanic Studies 40 (1963) 205-11.

${ }^{16}$ LUCAS OF TUY, Crónica de España, 413; MDHI, no. 483, p. 510: Primera Crónica General, 692; Los Anales Toledanos I y II, 172. 
ons of the significance of the victory grew clearer it was the Franci who took the brunt of the abuse but while Vincentius Hispanus took the battle as indication that Frenchmen were all Talk ${ }^{17}$, Lucas of Tuy informed his audience at the outset that Hispania was better than Rome. After all, Hispania possessed the body and the mission of a proto-martyr, Santiago, and the mission of the Apostle Paul, whereas Rome only had the body of Saint Paul ${ }^{18}$, an argument that, no doubt, like most effective propaganda, relied more on expectations of repetition than its own inherent intellectual cogency.

\section{THE LAS NAVAS OF History}

Of course, the story of the battle itself, suffered from retelling. The victorious chroniclers had, as victors are wont to do, exaggerated the force of their enemy, depicted the Christian situation as desperate, and had been somewhat prodigal with the truth as regards the heroism of their men and the splendour of their triumph. The studies of Huici Miranda and Eslava Galan on the Muslim chroniclers ${ }^{19}$, which they shrewdly use in conjunction with their Christian counterparts, certainly reveal a fuller and rather different story of the conflict: the war was possibly provoked by Barcelona and Castile, accurately judging the weaknesses of their Almohad enemy ${ }^{20}$. Al-Násir's chief advisor in North Africa, the highly capable Abd-al-Wahid, had warned him not to attempt the venture $^{21}$. Al-Nasir's army suffered from an extreme deficiency in organiza-

17 LINEHAN, History and the Historians, 296-7; DDEM, «Religion, nationalism and national identity in medieval Spain and Portugalw: Studies in Church History, 18 (1982) 192; R. BARKAI, Cristianos y Musulmanes en la España Medieval, Madrid 1984, 217-19: M. DEFourneAUX, Les Franpais en Espagne aux XIe et XIIe Siécles, Paris 1949, 182-93.

${ }_{18}$ LuCAS OF TUY, Crónica de España, 1-3; BARKAl, Cristianos y Musulmanes, 213-4; LINEHAN, History and the Historians, 357 8.

19 A. Huici MiRANDA, Estudios sobre la campaña de Las Navas de Tolosa, Valencia 1916; IDEM, Las Grandes Batallas de la Reconquista (cit.n.9), 307-12: J. ESLAVA GALAN, "Tácticas en la batalla de las Navas de Tolosas: Cuademos de estudios medievales 6-7 (1978-9)3953.

${ }^{20}$ The Bavi $5 n$ Almohade (Colección de Crónicas árabes de la Reconquista, ed. A. HuICI MiRANDA, 4 vols, Tetuán 1953, 2, 258) suggests the Muslim invasion followed Peter II's attack on the kingdom of Valencia (though that altack resulted from Muslim raids on the Catalan coast); GONZALEZ, Alfonso VIII (cit. n. 4)1, 981-2 shows that Alfonso was already preparing for war by repopulation and refortification of the frontier region from 1209; on this also, ESLAVA GALAN, «Tácticas en la batallan, 45; HUICI MIRANDA, Las Grandes Batallas, 227-8; IDEM, Historia Politica del Imperio Almohade, 2 vols, Tetuán 1956-7, 2, 414-6; M. GUAL CAMARENA, «Precedentes de la Reconquista valenciana»: Estudios Medievales 1 (1953) 208-12, 232-4.

21 GonZÁleZ, Alfonso VHI, 1, 983-4: HUICI MIRANDA, Historia Politica del Imperio Almohade, 2, 417; IDEM, Las Grandes Batallas, 231, ESLAVA GALAN, «Tácticas en la batalla», 45; R. LE TOURNEAU, The Almohad Movement, Princeton 1969, 82.

Proyección internacional de la iglesia hispana Hispania Sacra 51 (1999) 
tion - in 1211 the Christian fortress of Salvatierra (the Castilian Thermopylae) with a tiny garrison resisted a siege from the supposed might of the Almohad army for almost two months ${ }^{22}$. In all, the Almohad army was on campaign for seventeen months, had its pay suspended, provisions denied and inevitably faced the pains of excepcional hunger and heat ${ }^{23}$. To capital, Al-Násir, who was always a weak, pathetic and paranoid figure, a stammering academic, as Abd al Wahid al-Marákugl, who knew him, depicted him, had the governors of Fez and Ceuta decapitated on suspicion of mala dministration (for which act Le Tourneau accused him of 'unreasonable irritability') and executed his captain, the Andalusian Ibn Qadis, the defender of Calatrava, for surrender what was a hopeless position ${ }^{24}$. Needless to say that this was not good for morale, particularly not in an army where Berbers and Andalusian Muslims found unity an impossibility and co-existence a trial, and this is all to say that the Almohads had already contributed a great deal to their defeat before their conservative tactics further dented their chances on the battlefield ${ }^{25}$.

Victory, of course, did not seem inevitable to Castilian Christians who lived in the shadow of the catastrophic defeat of Alarcos in 1195'. 'Ab eis non minus quam mortem expectamus' wrote Alfonso VIII to Philip Augustus in 1212 , encouragingly calculating the prospects of martyrdom on the campaign ${ }^{27}$. 'Archiepiscope, ego et vos hic moriamur' Alfonso famously revealed to Rodrigo on the battlefield ${ }^{28}$; and when Berenguela received news of the

22 Al-Mu'yib fi' taljis ajbár al-magreb, ed. R. DOzY, Leiden 1881, 236; Colección de Crónicas Árabes (cit, n. 20), 2, 2678; DRH, BK.VII, c. 35, p. 256; G. CIROT (ed), «Chronique Latine»(cit, n. 9), 272; Los Anales Toledanos I y II. 172; HUICI MIRANDA, Historia Poltica del Imperio Almohade, 2, 418; IDEM, Las Grandes Batallas, 236-8; J. GoN̄I GAZTAMBIDE, Historia de la Bula de la Cruzada en España. Vitoria 1958, 112.- GONZÁLEZ, Alfonso VII, 1, 989-94. A. FOREY, «The Military Orders and the Spanish Reconquest in the Twelfth and Thirteenth Centuries»- Traditio 40 (1984) 212-3.

${ }^{23}$ Colección de Crónicas Árabes, 2, 262; ESLAVA GALAN, «Tácticas en la batalla», 46; HuICI MIRANDA, Las Grandes Batallas, 232; IDEM, Historia Política del Imperio Almohade, 2, 417; LE TOURnEAU, The Almohad Movemem, 83; C. SÁNCHEZ-ALbORNOZ, La España Musulmana, 2 vols, Buenos Aires 1960, 2, 285.

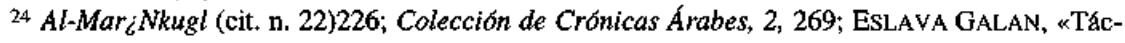
ticas en la batalla», 45-6; HUICI MIRANDA, Las Grandes Batallas, 232; IDEM, Historia Política del Imperio Almohade, 2, 417, 433-5; LE TOURNEAU, The Almohad Movement, 80, 83; SÁNCHEZALBORNOZ, La España Musulmana, 2, 283; GONZÁLEZ, Alfonso VIII, I, 988.

${ }^{25}$ ESLAVA Galan, «Tácticas en la batalla», 53; LE TouRnEAU, The Almohad Movement, 60, 78, 85, 110; Hulci MiRanda, Historia Política del Imperio Almohade, 2, 417.

${ }^{26} \mathrm{DRH}$, BK VI I, chs. 28-30, pp. 251-3, c. 33, p. 255; G. CIROT (ed.), «Chronique Latine» (cit, n. 9), 256-60; LUCAS OF TUY, Crónica de España (cit. n. 9), 407; GONZÁLEZ, Alfonso VHI, 1, 971; IDEM, Alfonso IX (cit. n. 4), 1, 92-3; GOÑ GAZTAMBIDE, Historia de la Bula (cit. n. 22), 96-7; HUlCI MiRANDA, Las Grandes Batallas, 114219.

27 GONZÁLEZ, Alfonso VIII, 3, no. 890, pp. 557-8.

${ }^{28} \mathrm{DRH}, \mathrm{BK}$. VIII, c. 10, p. 272. 
victory she refused to believe it until she had seen the letters from her father, so incredible did the whole thing seem ${ }^{29}$. Yet at a more comfortable distance it cannot but appear that the Almohads were always struggling because not only did they have to fight on two fronts - when putting down rebellion in Africa facing Christian revolt in the north and viceversa-but on the Iberian frontier, they could not generally field sufficient forces to cope with more than half of the sector involved. The Empire was too vast to be effectively governed, far greater than the means then held to sustain it. The sheer increase in Christian population and resources compared with the inability of the Muslims even at the height of their power to resettle the frontier regions, the development of Christian political and economic institutions, a developing military technology, in part brought about by the increasing ties with transpyrenean Europe, suggest that there is ample reason to concur with the troubadour view expressed after Alarcos (a victory which, it has been pointed out, brought no territorial gains): 'Before we' lost the Holy Sepulchre, and now we might lose Spain; for the first there are obstacles, but for the second we need fear neither sea nor wind'30.

\section{ROSCHER'S VIEW OF LAS NAVAS}

Negligible participation in a commonplace victory, would not be well for a discussion on the papal contribution on the path to Las Navas. Yet worse is to follow since Helmut Roscher, who in his excellent Papst Innocenz' III und die Kreuzzüge is one of the few historiaras to deal specifically and seriously with the papal role in the Las Navas campaign, following the account of the Hispanist Gams (who followed Rodrigo), went a step further than Rodrigo in suggesting Innocent was not only ineffective in the campaign but a hindrance to

${ }^{29}$ Letter of Berenguela to Blanche, in Recueil des historiens des Gaules et de la France, ed. M. BOUQUET and L. DELISLE, 25 vols, Paris 1738-1904, 19, 254.

30 The lament is attributed to Foulques of Toulouse by M. MLA Y FONTANALS, De los trovadores en Esparia, Barcelona 1861, 118-121; on Foulques, P. CABAU, «Foulque, marchand et troubadour de Marseille, moine et abbé du Thoronet, évêque de Toulouse (v.1155/116025.12.1231)»: Cahiers de Fanjeaux 21 (1986) 151-79; B. BOLTON, «Fulk of Toulouse: the escape that failed»: Studies in Church History 12 (1975) 83-93; S. STRONSKI, Folquet de Marseille, Cracow 1910. On Alarcos as a defensiva victory, LE TOURNEAU, The Almohad movement, 75, 101-3; HUICI, Historia Política del Imperio Almohade, 432. On Christian advance, C. BISHKO, «The Spanish and Portuguese Reconquest, 1095-1492»: K. SETTON (Ed. ), A History of the Crusades, 6 vols, Madison 1969-89, 3, 397 8, 400; POWERS, A Society Organized for War (cit. n. 9), 17; R. BARTLETT. The Making of Europe: Conquest, colonization and cultural change 950-1350, London 1994. 70-1.

Proyección internacional de la iglesia hispana Hispania Sacra 51 (1999) 
$\mathrm{it}^{31}$. Innocent's input was of negative value and Spain was not at the forefront of Innocent's desires. Excepting Celestine III (1191 1198) Innocent followed the traditions of the Twelfth Century Papacy and solely reacted to information that reached him from Spain. When Innocent sent his legate Rainier to Spain between 1198-1200, Rainier did not deal with the crusade against the Moor at all, but concentrated on the breaking of the illicit union between Alfonso IX of León and Berenguela. Innocent had put little effort into breaking any alliance between the King of León and the Moors or even securing Alfonso IX's neutrality. The initiative for the new crusade in 1210 came from Alfonso VIII and Prince Ferdinand of Castile; neither the plan of campaign nor the timing of it were Innocent's undertaking. Innocent did not help in the financing of the crusade. In Innocent's last letter to Alfonso VIII before the battle, his rousing cry read 'since all the world now lies in wickedness, we advise that if you can obtain a fair truce then you should take it, until the opportune time may come when you are able to beat the enemies of the Cross of Christ more easily' ${ }^{32}$.

Certainly, some element of what Roscher argued is true. Nobody would deny that the financial burden of the enterprise fell upon the kingdom of Alfonso VIII and most especially the Castilian church, and nobody would suggest that the Pope in Rome could have much idea about tactics of warfare in the Peninsula and how to organize the diverse forces that participated. But it can be argued that Roscher emphasised the negative over the positive elements in the contribution of Innocent III and his predecessors in the Iberian crusades and extracted from their proper context expressions that can be better understood in terms of papal policy over a broader period; it is in the long-term institutional and ideological development of the Peninsula that the Papacy makes its contribution. Moreover, if we take it that Las Navas is an unsurprising triumph, then we can argue that the importance of Las Navas ultimately lies less in the battle itself than in the myth of Spanish unity attached to it. And to that myth, by giving to Spain, as MacKay suggested 'a semblance of peace and unity' at Las Navas ${ }^{33}$, the Roman Curia over a broad period, and most especially Innocent III, had made a significant contribution to the Reconquista.

${ }^{31}$ H. RoscheR, Papst Innocenz $I I I$ und die Kreuzzüge, Góttingen 1969, 184-7; P. GAMS, Die Kirchengeschichte von Spanien, 6 vols, Graz 1956, 3, 111-154; cf. GOÑ GAZTAMBIDE, Historia de la Bula, 114; Unfortunately, G. MARTIN!, «Innocenzo III ed il finanziamento delle Crociate»: ASRSP 67 (1944) 309-335, adopted a nonlatitudinarian approach to the Crusades: 'Per non parlare della guerra di Spagna contro i Mor; , le crociate predicate da Innocenzo III furono tre: la quarta, la quinta, e, tra esse, la crociata contro gli Albigensi (p. 315).

32 ROSCHER, Papst Innocenz III und die Kreuzzüge, 184-7.

${ }^{33}$ A. MACKAY, Spain in the Middle Ages: From Frontier to Empire, 1000-1500, Macmillan $1977,33-4$. 


\section{THE RECONQUISTA}

What is the Reconquista? It is not an easy thing to define, because it means, as it meant, a great many different things to many people. It is a myth, the myth that between the Arab invasion of 711 and the conquest of Granada in 1492, the Hispanic peoples constantly fought or intended to fight for a liberation of the Peninsula from the Moors, and a return to an ancient 'Hispania' under a purif ied Gothic dynasty. And most often to this myth a belief in a prelapsarian state is added. 'Hispania' was lost through sin, through the bad life of Christians; the Reconquista is an expiation (in the recurring phrase) "pro peccatis nostris' and only through the assistance of God would the Church, people and kingdom be restored and Islam defeated. Both the Gothic and the religious elements of this myth had certainly existed from the end of the Ninth Century, if not before ${ }^{34}$.

But it is difficult to believe, in the absence of evidence, that the language of that false dawn in the reign of Alfonso $\mathrm{III} \mathrm{(866-910),} \mathrm{was} \mathrm{maintained} \mathrm{throu-}$ ghout the Tenth Century when the Christian rulers of the north lived in the shadow of the magnificent caliphate of Córdoba and during that long period until and, nearly everywhere, beyond the mid-Eleventh Century, when there was no opportunity for Christian military conquest. It is difficult not in large measure to concur with those who far more fruitfully interpret the Reconquista in a dif ferent light and more valuably stress the economic, political and social developments of Hispanic society; who do not see God or religion or ideas motivating any advances that were made but rather a series of raids and skirmishes fought for temporal prizes and most of ten fought by Christian kingdoms that were very much individual and opposed to one another; who point to the Cid, a mercenary who fights for his daily bread and for either side, Christian and Muslim, and concur with Fletcher that 'the evidence -or lack of it- suggests that Spaniards of the eleventh and early twelfth century were not interested in a programme of Reconquest ${ }^{35}$.

${ }^{34}$ For views of the Reconquista, J. N. HILLGARTH, «Spanish historiography and Iberian reality»: History and Theory 24 (1985) 23-43; J. A. MARAVALL, El Concepto de España en la Edad Media, Madrid 1964, 294; R. MÉNENDEZ PIDAL, El imperio hispánico y los cinco reinos, Madrid 1950, 205; IDEM, La España del Cid, Buenos Aires 1939, 30, 51, 162; D. LOMAX, La Reconquista, Barcelona 1984, 9-13; C. SANCHEZ-ALBORNOZ, Spain: A Historical Enigma, 2 vols, Madrid 1975, 1, 21; J. VICENS VIVES, Approaches to the History of Spain, University of Califomia 1970, 46; J. MARIAS, Understanding Spain, University of Michigan 1990, 89; J. ORTEGA Y GASSET, Invertebrate Spain, London 1937, 43.

35 R. FLETCHER. «Reconquest and Crusade in Spain c. 1050-1150m: Transactions of the Royal Historical Society 37 (1987) 34; IDEM, The Quest for El Cid, London 1989, 4; R. CoLLINS, Early Medieval Spain: Unity in Diversity, 400 1000, London 1983, 235; B. WHEELER, «The Reconquest of Spain before 1095»: K. SETTON (Ed.), A History of the Crusades (cit.n. 30), 1, 31-9; R. DOZY, Re-

Proyección intemacional de la iglesia hispana Hispania Sacra 51 (1999) 


\section{RECONQUISTA AND CRUSADE}

Hesitancy during the last decades of the Eleventh Century, and then emphatically in the first two decades of the Twelfth, what we call the Reconquis. $t a$, however deformed it may then have been, was transformad by the Papacy into a matter for all Christianity, converted into what we call a Crusade. The Spanish crusade, preached as a battle for the inheritance of Christ, was afforded much of the same crusading terminology as the battle for the Holy Land, elevated with many of the privileges and advantages of the spiritual and temporal order conceded to the Eastern crusaders, and compared to though notequated with it by successive popes and councils ${ }^{36}$. It was increased in value by the insistence of Urban II and Paschal II conscious of the threat from Ben Yusuf, that the Spanish were not to go crusading to Jerusalem (an insistence consistently ignored and then dropped) ${ }^{37}$; in the protection of those military orders that came from outside of the Peninsula, the Templars and the Hospitallers, who played such a significant role in the Aragonese reconquest in particular,

cherches sur l'histoire et la littérature de l'Espagne pendant le Moyen Age, 2 vols, Leiden 1860, 2, 233; J. RuIz DOMÉNEC, «El significado histórico de la batalla de Las Navas de-Tolosa y sus consecuencias»: M. A. LADERo QUESADA (Ed.), Historia General de España y América, 4, 586-90; A. BARBERo, La formación del feudalismo en la Pentnsula ibérica, Barcelona 1978; A. BARBERo and M. VIGIL, Sobre los Origines sociales de la Reconquista, Barcelona 1974; S. DE MOXÓ, Repoblación y sociedad en la España Cristiana medieval, Madrid 1979; J. -L. MARTIN, Evolución económica de la peninsula ibérica (siglos VI-XIJ), Barcelona 1976; L. NELSON, «Internal Migration in Early Aragon: The Settlers from Ena and Baón»: Traditio 40 (1984) 131; E. LoURIE, «A Society organizad for War: Medieval Spains: Past and Present 35 (1966) 68.

36 J. BRundaGe, Medieval Canon Law and the Crusader, University of Wisconsin 1969, $25 \mathrm{n}$. 91; M. BULL, Knightly Piety and the La y Response to the First Crusade: The Limousin and Gascony, c. 970 c. 1130, 'Oxford 1993, 12, 108; IDEM, «The Roots of Lay Enthusiasm for the First Crusade»: History 78 (1993) 354; H. E. J. CowDREY, «The Genesis of the Crusade: The Springs of Western Ideas of Holy Warn: T. P. MurPHY (Ed.), The Holy War, Ohio State University 1976, 25; IDEM, «Pope Gregory VII's 'Crusading plans' of 1074»: B. Z. KeDAR, H. E. MAYER, R. C. SMAIL (Eds), Ourremer, Jerusalem 1982, 40; A. FERREIRO, «The siege of Barbastro, 1064-5: a reassessment»: Jounal of Medieval History, 9 (1983)129-44; FLETCHER, The Episcopate in the Kingdom of Leon (cit. n. 4), 217; IDEM, «Reconquest and Crusade», 423; IDEM, Saint James's Catapult: The Life and Times of Diego Gelmirez of Santiago de Compostela, Oxford 1984, 297-8; P. FRANCISCO QUECEDO, «Influencia diplomática y económica de España en Tierra Santa»: Hispania 9 (1949) 4; A. GARCfA Y GARCIA, «Reforma Gregoriana e idea de la 'Militia Sancti Petri' en los reinos Ibericos»: Studi Gregoriani 13 (1989) 260 2; IDEM, «El Concilio IV Lateranense (1215) y Francia»(cit. n. 8), 74, J. GILCHRIST, «The Erdmann thesis and the canon-law, 1083-1141»: P. EDBURY (Ed.), Crusade and Settlement, Cardiff 1985, 37-45; GOÑ GAZTAMBIDE, Historia de la bula, 53-80; J. RLLEY-SMITH, What were the Crusades?, London 1977, 16 7; ROSCHER, Papst Innocenz II' und die Kreuzzitge, 176.

${ }^{37}$ GOÑ GAZTAMBIDE, Historia de la Bula, 60, 64-5; M. J. GUDIOL, «De peregrins i peregrinatges religiosos Catalans": Analecta Sacra Tarraconensia 3 (1927) 93 119; A. UBIETO ARTETA, «La participación navarro-aragonesa en la primera cruzada»: Príncipe de Viana 8 (1947), 357-83; ROSCHER, Papst Innocenz $\mathrm{II}^{\prime}$ und die Kreuzzüge, 176. 
and in the encouragement of the new foundation of Iberian confratemities andmilitary orders, some like the militia of Zaragoza or the order of Mountjoy, ephemeral, but others - Calatrava, Alcantara, Santiago- extraordinary in their history and holding to an administrativa unity and purpose that transcended regnal politics ${ }^{38}$; in the protection of monasticism, particularly the Cistercians and the Premonstratensians, whose role in the repopulation of the frontier region should not be underestimated, and whose administrativa and organisational skills allowed them to exploit the no-man's land, businessmen to defeat the Moors, the true heroes of the wild frontier; ${ }^{39}$ in the legates sent to the peninsular figures of the first rank, -for instances, Cardinal Hugh Candidus (perhaps not an auspicious start), but Cardinal Rainier in 1090, who became Paschal $\mathrm{I}$ in 1099, Cardinal Boso, who had two legations and also participated in the Balearic venture of 1115; or Nicholas Breakespeare who in 1149

38 A. J. ForeY, The Templars in the Corona de Aragón, Oxford 1973, 159-80; IDEM, "The Military Orders and the Spanish Reconquest» (cit. n. 22), 210; IDEM, «The Order of Mountjoy»: Speculum 46 (1971), 250-66; J. MARTí BONET, «Privilegios Papales del Archivo Diocesano de Barcelona (Celestino II a Celestino Ul, a. 1144 al 1196)11: Anthologica Annua 27 (1980) 779-820; M. L. LEDESMARUBlo, Templarios y Hospitalarios en el Reino de Aragon, Zaragoza 1981, 65; D. LOMAX, La Onden de Santiago 1170-1275, Madrid 1975, 79; DEM, «The Order of Santiago and the Kings of León» : Hispania 18 (1958) 3-37; J. O'CALLAGHAN, «The foundation of the order of Alcántara, 1176-1218»: Catholic Historical Review 47 (1962) 471-86; IDEM, The Spanish Military Order of Calatrava and its affiliates, London 1975; F. R. DE UHAGÓN, «Índice de los documentos de la orden militar de Calatrava»: Boletín de la Real Academia de la Historia 35 (1899) 67-9; E. BENITO RUANO, «Las Ordenes militares españoles y la idea de Cruzada»: Hispania 16 (1956) 3-15 - Generally, on the military orders in Spain, the bibliographical essay of LOMAX, Las órdenes militares en la Peninsula Iberica durante la Edad Media, Salamanca 1976, and volume 11 (1981) of Anuario de Estudios Medievales.

${ }^{39}$ M. COCHERIL, «Espagne Cistercienne»: Dictionnaire d'histoire et de géographie ecclesiastiques 15 (1963) 944-69; IDEM, «L'implantation des abbayes cisterciennes dans la peninsule ibérique»: Anuario de Estudios Medievales 1 (1964) 217-87, L. MCCR'ANK, «The Cistercians of Poblet as landlords: protection, litigation and violence on the Medieval Catalan frontier»: Citeaux commentarii cistercienses 26 (1975) 263-8; IDEM, «The Cistercians of Medieval Poblet as Medieval frontiersmen»: Estudios en Homenaje a Don Claudio Sánchez Albornoz en sus 90 años, Anejos, de Cuademos de Historia de España 2 (1983)313-60; IDEM, "Monastic inland empires and the Mediterranean coastal reconquest in New Catalonia, 1050 1276 «B. F. TAGGIE, R. W. CLEMENT, and J. E. CARAWAY (Eds.), Spain and the Mediterranean, Thomas Jefferson University 1991, 32; J. -B. MAHN, $L$ 'Ordre Cistercien et son gouvernement des origines au milieu du XIIIe siécle (1098-1215), 119-131; M. BASSA I ARMENGOL, «Algunes consideracions sobre els segells Cistercenes de la primera época»: Col-loqui d'História del Monaquisme Catalá 1 (1966) 21 61; C. HIGOUNET, «Un mapa de las relaciones monásticas transpirenaicas»; Pirineos 7 (1951) 543-53; N. BACKMUND, Monasticon Praemonstratense, 3 vols, Straubing 1956, 154-208; IDEM, «La Orden Premonstratense en España « : Hispania Sacra 35 (1983) 57-85; T. MORAL, «Los Premonstratenses en España: Guión para un estudio histórico-crítico de la orden»: Hispania Sacra 21 (1968) 57-85; E. CoRREDERA GUTIÉrREZ, «Los Condes soberanos de Urgel y los Premonstratensess: Analecta Sacra Tarraconensia 36 (1963) 33-102, 209 82.

Proyección internacional de la iglesia hispana Hispania Sacra 51 (1999) 
witnessed the labour and sweat of Ramon Berenguer IV in the capture of Tortosa and Lleida, and who in 1154 became Hadrian $\mathrm{IV}^{40}$.

It was through legates in combination with the lberian church, when it was willing and able, that the Papacy sought to bring about peace between the Christian kingdoms by emphasising what Spaniards knew but needed reminding of, that it was disharmony, the sin of division. that led to defeat. Herein lay the great contradiction and beauty of the papal argument in Spain - the papacy appealed to a higher sense of unity, a defence of the Regnum Hispanie (at a time when Hispanic chanceries were recognising the reality of the five kingdoms) and, beyond this, of the Christian Faith, and at the same time insisted on fragmentation, on protecting the rights of each individual ruler within his realm against the dominion of a greater kingdom (usually Castile) and it was this idea of a higher sense of unity in operation over an accepted fragmentation, that was the most successful articulation given to what Maravall called the unitary conception of the kingdom of Spain with the system of a plurality of kings ${ }^{41}$.

\section{THE PAPACY AND THE LANGUAGE OF THE RECONQUISTA}

This is not to say that somehow the political and economic interests of the participants ceased to be the signif icant $f$ actors in the development of the Peninsula: of course, they did not and they never would ${ }^{42}$. On the whole kings, and bishops (who were shaped in the kings' likeness), paid little attention to the mandates of legates and popes ${ }^{43}$; nor is it to forget that there were other

40 Much work remains to be done on papal legates in the Península. See G. SÁBEKow, Die päpstlichen Legationen nach Spanien und Portugal bis zum Ausgang des XII. Jahrhunderts, Berlin 1930; more generally, H. ZIMMERMANN, Die päpstlichen Legaten in der ersten Hälfte des 13. Jahrhunderts, Paderborn 1913; P. BLET, Histoire de la Représentation Diplomatique du Saint Siége des origines á 1 'aube du XIXe siécle, Rome 1982.

${ }^{41}$ Maravall, El Concepto de España (cit. n. 34), 357 8; A. Oliver, «'Regnum Hispaniae' en el programa de reforma de Gregorio VII»: Studi Gregoriani 14 (1991) 76-7; LINEHAN, «Religion, nationalism and national identitym(cit. n. 17), 176.

42 J. MíngUEZ, La Reconquista, Madrid 1989, 8.

43 S. BARTON, «The Count, the Bishop and the Abbot; Armengol VI of Urgel and the Abbey of Valladolid»: English Historical Review 111 (1996) 99-100; R. FLETCHER, «Regalian Right in Twelfth Century Spain: the case of Archbishop Martín of Santiago de Compostelas: Journal of Eccleslastical History 28 (1977) 359; IDEM, Saint James's Catapult (cit. n. 36), 210; P. LINEHAN, «The Synod of Segovia»: Bulletin of Medieval Canon Law 10 (1980) 39; D. LOMAX, «Don Ramon, bishop of Palencia (1148-1184)»: Homenage a Jaime Vicens Vives, Barcelona 1965, 1, 288; B. REILLY, «On getting to be a bishop in León-Castile: The 'Emperor' Alfonso VII and the Post-Gregorian Church»: Studies in Medieval and Renaissance History 1 (1978) 67-8. 
externas forces, particularly increased contacts across the Pyrenees and, above all, the zealotry of the Almoravid rulers, that shaped developments ${ }^{44}$. It is however to say that the royal ideology of the Reconquista, previously poorly formulated, from the late Eleventh Century, while holding to its patriotic origins, is very much to be understood as a papal imposition of those notions, as they have been called theological, feudal, even apocalyptic'45, which were adopted for the Crusades, on to societies that were ripe for the reception of such formulae. The language of the Reconquista is the language of the Reformed Papacy and is more fully expressed in the letters of popes, particularly from Gregory VII to Paschal II, than in any other sources: 'Tota Hispania' , 'recuperare', 'restituere', 'liberare', 'reparare', 'reddere, 'revocare', irestaurare', 'perdere'- the papal letters are packed with the words of the Reconquista ${ }^{46}$. It is this language, likewse adopted by Cluny ${ }^{47}$, that gradually develops in the Peninsula. We see the Iberian formualation of the idea of the Reconquista given verve by the reformers in 1076 in Sancho Ramírez's desire to expand the Church of Christ, to recover it and to liberate it from the enemies of the Crucif ied ${ }^{48}$, or with Alfonso VI in 1086 speaking of "land stolen from the Church and 'restoring the Faith' ${ }^{49}$, but far more expressively formulated by Ramon Berenguer IV in a grant of 1143 to the Templars 'for the crushing, conquest and expulsion of the Moors, for the exaltation of the Faith and religion of Sacred Christianity ... for the exercise of the office of a military order in the region of Spain against the Saracens, for the remission of my sins, for the honour of God, who honours those honouring Him, and for the salvation of the soul of my father ${ }^{50}$. This is to say, prior to the second crusade, not only religious but

\footnotetext{
44 BisHKo, «The Spanish and Portuguese Reconquest « (cit. n. 30), 3989; DefourNEAUX, Les Frangais en Espagne (cit. n. 17), 126-193; cf. BULL, Knightly Piety (cit. n. 36), 72; L. NELSON, «Rotrou of Perche and the Aragonese Reconquest»: Traditio 26 (1970) 114; D. LOMAX, «Catalans in the Leonese Empire»; Bulletin of Hispanic Studies 59 (1982) 191.

45 GILCHRIST, «The Erdmann Thesis» (cit. n. 36), 41; IDEM, «The Papacy and the War against the 'Saracens', 795-1217»: International History Review 10 (1988) 190.

46 Especially, $M D H$, nos. 13 , p. $24 ; 24$, p. $40 ; 27$, p. $43 ; 29$, p. $46 ; 32$, p. $50 ; 42$, p. $61 ; 45$, p. 65 ; 47 , p. $67 ; 59$, p. $76 ; 62$, p. $79 ; 63$, p. $80 ; 72$, p. $89 ; 76$, p. $92 ; 80$, p. 97 ; MARAVALL, El Concepto de España, 287.

${ }^{47}$ H. E. J. COWDREY, «Cluny and the First Crusade»: Revue Bénedictine 83 (1973), 285-311; IDEM, The Cluniacsandthe Gregorian Reform, Oxford 1970, 219, 227, 246-7; BiSHKo, «The Spanish and Portuguese Reconquest». 399,- FLETCHER. The Quest for El Cid (cit. n. 35), 145-6.

48 Documentos correspondientes al reinado de Sancho Ramirez, ed. J. SALARRULLANA DE DIOS and E. IBARRA Y RODRIGUEZ, 2 vols, Zaragoza 1907-13, 1, no. 48, p. 188.

${ }^{49}$ Cited FLETCHER, «Reconquest and Crusade in Spain» (cit. n. 35), 39.

50 Colección de documentos inéditos del Archivo General de la Corona de Aragón, ed. P. DE BofARULl Y MASCARó, 42 vols, Barcelona 1847-1973, no.63, pp. 93-9; G. CONSTABLE, «The Second Crusade as seen by contemporaries»: Traditio 9 (1953) 232; cf. C. TYERMAN, «Were there any crusades in the Twelfth Century?»: English Historical Review 110 (1995)561-2.
}

Proyección internacional de la iglesia hispana Hispania Sacra 51 (1999) 
seculars of the greatest inf luence sanctioned the Reconquista as something far above temporal aspirations.

\section{Celestine III AND THE RECONQUISTA}

Yet further setbacks accompanied renewed optimism. After the death of Alfonso VII (1126-1157) and the break-up of the Leonese-Castilian empire, this decimation of Spanish unity produced a further period of unsettled relationships between the Spanish kings. Effectively the wars among the Five kingdoms were almost continua in the last third of the Twelfth Century, and at least seventeen treaties in the half century after 1157 would not lead one to argue for a superabundance of love between the Christian kings ${ }^{51}$. It was Celestine III, for half a century papal expert on Hispanic affairs, and twice legate in the Peninsula, who forcefully urged internar pacification ${ }^{52}$. Zerbi has elucidated Celestinels role: It was primarily Celestine who insisted on the l'reges Hispaniarum' as a body inside the spiritual Christian unity, and demanded from them an alliance and co-operation. In virtue of his office of pastor of the universal church, Celestine consideres it his duty to eliminate all discord and to guarantee tranquility, particularly at a moment, after the battle of Hattin (4 iuly 1187), when all energies ought to be put into defeating the Saracens. To fight the evil in Iberia, Celestine required a community of kingdoms that respected the laws of God and the laws of the Church and that, united in peace, conducted in solidarity the battle for the defence of Christianity ${ }^{53}$.

51 MANSILLA, «Inocencio Ш y los reinos hispanos» (cit. n. 4), 13; MÉNENDEZ PIDAL, El Imperio Hispánico (cit. n. 34) F 180; LoMAX, La Reconquista (cit. n. 34), 147-161; GONZALEZ, Alfonso VII (cit. n. 4), passim; BISHKO, «The Spanish and Portuguese Reconquest «(cit. n. 30), 412-417.

52 P. ZERBl, Papato, Impero, e 'Respublica Christiana' dal 1187- 1198, Milan 1955, 47; F. FTA, «Primera legación del Cardenal Jacinto en España. Bulas inéditas de Anastasio IV: Nuevas luces sobre el concilio nacional de Valladolid y otros datos inéditos»: Boletén de la Real Academia de la Historia 14 (1889) 530-55; IDEM, "Catorce bulas de la catedral de Pamplona, que faltan a la colección de Loewenfeld, desde el año 1096 hasta el de 1196 -observaciones críticas sobre un concilio de Calahorra que presidió el cardenal Jacinto en 1155»: Boletín de la Real Academia de la Historia 14 (1889) 495-509; Alfontso II, Rey de Aragón, Conde de Barcelona y Marqués de Provenza: Documentos (1162-96), ed. A. I. SÁnCHEz CASABón, Zaragoza 1995, no. 161, p. 237; G. Gonzalvo I Bou, Les Constitucions de Pau i treva de Catalunya (segles XI-XII), Barcelona 1994, no. 12, pp. 53-60, no. 13, pp. 61-67; Burchardo et Cuonradi Urspergensium Chronicon, MGH. ss. 23, 378-9 reports a third legation to Spain being unexpectedly abandoned because Cardinal Giacinto was elected Pope. On this, J. E. SAYERS, Papal Govermment and England during the Pontificate of Honorius III (1216-1227), Cambridge 1984, 10-1.

53 ZERBI, Papato, 148-159; Roscher, Papst Innocenz III' und die Kreuzzige (cit. n. 31), 17981; GoÑ GAZTAMBIDE, Historia de la Bula (cit. n. 22), 96m9; ForEY, «The Military Orders and the Spanish Reconquest) (cit. n. 22), 220; FLETCHER, The Episcopate in the Kingdom of Leon (cit. ת. 4), 
Celestine's plans came close to success. Through a series of councils, legations and bulls, he secured truces between the warring Christian factions, threatened with excommunication those kings who sided with the Moor against Christian powers. bolstered the prestige of Portugal and Navarre in particular against Castilian hegemony, encouraged the military orders in Spain to continue the struggle with the infidel despite the truces which existed between Christian and Moorish rulers, and was generous in his grants of the remission of $\sin$ for all those who fought against the Moors out of devotion ${ }^{54}$. But near was not enough. Celestine could not overcome the festering distrust between Castile and León and not victory but the battle of Alarcos in 1195, humiliation and a total disintegration into Christian civil war faced the ageing pontiff ${ }^{5 s}$. While Alfonso II (1162-1196) of Aragon responded to Celestine's renewed pleas with a pilgrimage for unity to Compostel $a^{56}$, the Pope was left with a series of uneasy truces between the Christian kings, the knowledge that Navarre and León would rather side with the Moor than Castile, the knowledge that Castile and Aragon were intent on carving up Navarre, and that peace in Christian Hispania ultimately rested upon the incestuous marriage of Alfonso IX and Berenguela, that had been agreed in order to close the LeoneseCastilian war of $1197^{57}$.

\section{INNOCENT III AND THE RECONQUISTA}

Innocent held the crusades as his primary occupation. A man of the very highest intellectual calibre, possessed of an indomitable will and a rare clarity of vision, without ever bearing arms the most passionate of the Crusaders, for

218, points to increased papal activity in Spain after Hattin; on this also RIVERA, La Iglesia de Toledo (cit. n. 4), 219-37.

${ }^{54}$ Papsturkunden in Spanien, 2: Navarra und Aragon, ed. P. KEHR, Berlin 1928, nos. 200-1, pp. 504-7, nos. 229 30, 588-93; Papsturkunden in Portugal, ed. C. ERDMANN, Berlin 1927, nos. 127158, pp. 348-79; Regesta pontificum romanorum, ed. P. JAFFE, rev. S. LOEWENFELD [hereafter JLI, Leipzig 1885, 17265; RIVERA, La Iglesia de Toledo, no. 79, p. 228; F. FITA, «El Concilio de Lérida en 1193 y S. María la Real de Nájera: bulas inéditas de Celestino III, Inocencio III y Honorio III»: Boletín de la Real Academia de la Historia 26 (1895)332-83.

55 HUICl Miranda, Las Grandes Batallas (cit. n. 9), 184-210; LOMAX, La Reconquista (cit. $\mathrm{n}$. 34), 154-160; GONZALEZ, Alfonso IX ( cit. n. 4), 1, 72 3; IDEM, Alfonso VIII (cit. n. 4), 1, 383.

56 A. UBieto ARteTA, «La peregrinación de Alfonso II de Aragán a Santiago de Compostela»: Estudios de la Edad Media de la Corona de Aragón 5 (1952) 438 52.

57 DRH, Bk. VII, chs. 30-2, 253-5; LUCAS OF TƯY, Crónica de España (cit. n. 9), 408-11; G. CIRoT (Ed.), "Chronique latine» (cit. n. 9)263-66; Los Anales Toledanos (cit. n. 9), 161; Primera Crónica General (cit. .. 9), c. 1003, pp. 681-2; The Chronicle of San Juan de la Peña (cit. n. 9), 58; ZERBl, Papato, 156-70; GONZALEZ, Alfonso VIII, 1, 383-4; IDEM, Alfonso IX. I, 83-100.

Proyección internacional de la iglesia hispana Hispania Sacra 51 (1999) 
him the defence of Christianity was the vital aim. He was deeply convinced that the loss of Christian lands, in Spain and in the East, was the product of the Christian's sinful nature and their fondness for petty intemecine warfare. In his famous encyclical of 1198 for the Fourth Crusade, post miserable a plea for a renewed Christian world united in peace to achieve victory over the Muslim usurpers, Innocent showed his particular consciousness of this problem in Spain, of the disaster of Alarcos, and the importance of the Hispanic crusade in the spiritual unity that would bring about victory in the Holy Land: 'Where is your God to rescue you from our hands?' Innocent has the Muslims cry at the Christians. 'We have desecrated your Holy places and hold them in our hands after we have taken them by storm. We have broken the lances of the Gauls, brushed aside the assaults of the English, cut to pieces the forces of the Germans, and now tamed the Spaniards for a second time. Where is your God ${ }^{58}$,

Innocent in Spain gave himself the same objectives as Celestine- peace and unity. How was this to be achieved? Essentially by using the resources and building on the strategy that the Papacy had developed over a century and a half. Firstly, peace and unity could only come through a society free from sin - only a society free from sin could be properly organizad for war. Thus, for instance, the incestuous marriage of Alfonso and Berenguela, for the Hispanic rulers a logical dynastic strategy, was for Innocent a breach of Divine law and hence a means to defeat. The Christian people were scandalized, wrote Innocent to Archbishop Peter of Compostela, that now the sins that had led to such disasters and persecutions in the East were being transferred to the West ${ }^{59}$. Thus in sending his legate, the saintly and erudite Cistercian Rainier of Ponza (an old friend of Joachim of Fiore and later Innocent's confessor) to break the marriage, Innocent was from his point of view, furthering the Reconquista: 'We have sent you to the kingdoms of Spain to secure peace between the rulers and dissolve iniquitous unions' 60 .

58 Die Register Innocenz' II, 1 Pontifikatsjahr, Ed. 0. HAGENEDER and A. HAIDACHER, GrazKoln 1964, no. 336, p. 550; Potthast, 347; MPL, 214, 309; RosCHER, Papst Innocenz'III und die Kreuzzilge, 173-4; J. RuPP, L'Idée de Chrétienté dans la pensée pontificale des origines á Innocent III, Paris 1939, 96-123; P. RouSSET, «La notion de Chrétienté aux XIe et XIle Siécles»: Le Moyen Age 69 (1963) 191 203; P. CoLE, The Preaching of the Crusades to the Holy Land, 10-95 1270, Cambridge Masssachusetts 1991, 80-1.

${ }^{9}$ Die Register Innocenz' $I I, 2$ Pontifikatsjahr, ed. 0. HAGENEDER, W. MALECZEK and A. A. STRNAD, Rome 1979, no. 72, p. 128; MDHI, no. 196, p. 210; Pothast, 716; MPL 214, 610; Linehan, History and the Historians (cit, n 1 . 2), 166,- the Hisparic canonists' ruthless treatment of Innocent's controversias crusading-marriage decretals 'Quod super his' and 'Ex Multa' may well relate to resentment over the Pope's actions in the Peninsula. See J. BRUNDAGE, «The Crusader's wife: A canonistic quandary": Studia Gratiana 12 (1970) 427-41.

60 Die Register Innocenz' III, 1 Ponifikatsjahr, no. 92, pp. 132-4; MDHI, no. 138, p. 168; Potthast, 81; B. BOLTON, «For the see of Simon Peter: The Cistercians at Innocent's nearest frontier», 1 - 
Secondly, peace and unity could only be achieved by maintaining the balance of power within the Peninsula through the respect for the validity of the younger kingdoms and, in turn, their acknowledgement of the necessity of papal over Castilian protection. It is what Gregory VII has in mind when he favours Sancho Ramírez in the $1070^{\prime} \mathrm{s}^{61}$, and Alexander III in 1179 when he acknowledges Afonso Henriques as King of Portugal ${ }^{62}$, and Celestine III when granting Sancho VII the title 'rex Navarrorum' in $1196^{63}$. Innocent, rather than forming Spain around Castile, attempted to fortify the political position of the different kings. For instance, this is partly why Innocent initially was so keen to protect Sancho VII of Navarre from the invasion of Alfonso VIII and Peter II in 1199, though Sancho's subsequent alliance with the Saracens rendered him indefensible ${ }^{64}$, and probably one reason why Peter II was crowned in Rome in $1204^{65}$.

20 and F. ROBB, «'Who hath chosen the better part? (Luke 10, 42) ' Pope Innocent III and Joachim of Fiore on the diverse forms of religious life», 157-170 : J. LOADES (Ed.), Monastic Studies: the continuity of Tradition, Bangor 1991; I. RAMILA, «Inocencio III y la cruzada de Las Navas de Tolosa»: Revista de archivos, bibiotecas y museos 31 (1928) 455-64, stresses the unity point.

${ }^{61}$ GREGORY VII, Das Register. ed. E. CASPAR, 2nd edn. 1 vol. in 2, MGH Epistolae Selectae, 45, Berlin 1955, i, no. 63, pp. 91-2; MDHI, no. 9, pp. 16-7; JL, 4841; D. SMITH, «Sancho Ramírez and the Roman Rite»: Studies in Church History 32 (1996) 100-1; J. -M. SOTO RÁBANOS, «Introducción del Rito Romano en los Reinos de España. Argumentos del Papa Gregorio VI»: Studi Gregoriani 14 (1991) 171; On Sancho's subsequent dealings with Rome, R. SOMERVILLE, Pope Urban II, The Collecti o Britannica, and the Council of Melfi (1089), Oxford 1996, 97-8, 157-8.

$62 \mathrm{JL}, 13420 ;$ M. PACAUT, Alexandre III: Etude sur la conception du Pouvoir Pontifical dans sa pensée et dans son oewvre, Paris 1956, 221-2; C. ERDMANN, Das Papsttum und Portugal im ersten Jahrhundert der portugiesishcen Geschichte, Berlin 1928, 29-32, 49-50; J. FRIED, Der päpstiche Schutz für Laienfiursten. Die politische Geschichte des päpstlichen Schutzprivilegs fuir Laien, Heidelberg 1980, 72-3; III y A. GARCfA Y GARClA, «Alejandro los Reinos Ibéricos»; Miscelanea Rolando Bandinelli Papa Alessandro III, Siena 1986, 244.

${ }^{63}$ Papsturkunden in Spanien 2 (cit. n. 54), no. 230, 591-3; P. KEHR, «El Papado y los reinos de Navarra y Aragón hasta mediados del siglo XII «Estudios de Edad Media de la Corona de Aragón, 2 (1946) 167-8; Zerbi, Papato, 158-60; J. M. LACARRA, Historia del Reino de Navarra en la Edad Media, Pamplona 1975, 228.

${ }^{64} M D H I$, no. 181, pp. 197 8; Potthast, 597; MPL, 214, 509; DRH, Bk VL. chs. 30-2, pp. 252-4; G. CIROT (Ed), «Chronique Latine», 265-6; LUCAS OF TúY, Cronica de España, 408; Anales Toledanos, 165; C. SMITH, Christians and Moors in Spain, 3 vols, Warminster 1988-90, 2, 6-11; Colección Diplomática de Santa María de Roncesvalles (11271300), ed. M. I. OsTOLAZA, Pamplona 1978, no. 22, pp. 106-8; ZERBI, Papato, 157 60; LACARRA, Historia del reino de Navarra, 228-9; GoNZÁlEZ, Alfonso VIII, 1, 486; GONZALEZ, «Reclamaciones de Alfonso VIII a Sancho el Fuerte y tratado del reparto de Navarra en 1198»; Hispania 3 (1943) 545-68; A. UBIETO ARTETA, «Navarra Aragón y la idea imperial de Alfonso VII de Castilla»: Estudios de la Edad Media de la Corona de Aragón, 6 (1956)41-82.

65 MDHI, no. 307, pp. 339-41; Potthast, 2322, 2361; MPL, 215, 550; FRIED, Päpstliche Schutz, 208; PALACIOS, La Coronación (cít.n. 3), 167; SMTTH, Innocent III and Aragon-Catalonia (cit. n. 3), $36-94$.

Proyeccíón internacional de la iglesia hispana Hispania Sacra 51 (1999) 
Thirdly, peace and unity were to be achieved necessarily through the reform of the Iberian church. The reform of the Church was the essential prerequisite for the defeat of the Moor - the protection of the Church from the interference of the lay power and the support of the tradicional and newer military orders was vital here; as was Roman interference in the internar disputes of the Church, such as that highlighted by the anonymous author of the Gesta Innocentii between Braga and Compostela, a result, like most of these disputes of trying to adapt preconquest structures to Reconquest situations, where Innocent successfully juggled with the problem of Compostela holding metropolitan rights over half the sees of Portugal and Braga rights over half the sees of León ${ }^{66}$, or the notorious dispute between Huesca and Lleida in the East of the Peninsula, which had been going on long before either city had been recaptured from the Moors, and where Innocent imposed a solution that was so admirable judicious that undoubtedly neither party was able to question papal justice or, indeed, decide whether it had eventually won the game ${ }^{67}$. These disputes drained both the spiritual and physical energies of the land, and this is why Innocent was so impatient to put an end to them.

The reform of the Church, the establishment of peace, the spiritual purification of Christendom - these were the essential elements in the promotion of the Hispanic Crusade.

\section{INNOCENT III AND THE LAS NAVAS CAMPAIGN}

It was with these objectives firmly in mind that Innocent acted in the Las Navas campaign. The exact circumstances of the initiation of the Crusade are

66 Gesta Innocentii, c. 42, MPL, 214, 81-2; D. MANSILLA, «Disputas diocesanos entre Toledo, Braga y Compostela en los siglos XII al XV»: Anthologica Annua 3 (1955) 114-29; IDEM, «Origines de la organización metropolitana en la iglesia españolas: Hispania Sacra 12 (1959)255-91; IDEM, «Formación de la provincia Bracarense después de la invasión árabe»: Hispania Sacra 14 (1961) 5 25. At the height of the Las Navas campaign, Innocent would be dealing with a dispute on diocesan limits between Toledo and Avila (Documentación Medieval de la Catedral de Avila, ed. A. BARRIOS GARCLA, Salamanca 1981, no. 48, p. 43 (13/05/1212». Border disputes between Burgos and Osma would bother Innocent almost to his dying day (Documentación de la Catedral de Burgos (1184I222), ed. J. M. GARRIDO GARRIDO, Burgos 1983, no. 480, pp. 294-5, no. 491, pp. 307-9).

${ }^{67} \mathrm{MDHI}$, no. 271, pp. 292-300; Potthast, 1925; MPL, 215, 70; E. GROS BíTRIA, Los límites diocesanos en el Aragón Oriental, Zaragoza 1980; F. BALAGUER, «Los límites del obispado de Aragón y el concilio de Jaca de 1063»: Estudios de la Edad Media de la Corona de Aragón 4 (1951) 69-138; F. ARROYO LLERA, «El dominio territorial del obispado de Roda (siglos XI y XII)»: Hispania Sacra 22 (1969) 69-128; A. DuRAN GUdiol, «La Santa Sede y los obispados de Huesca y Roda en la primera mitad del siglo XII»: Anthologica Annua 13 (1965)35-134; A. UBIETO ARTETA «Disputas entre los obispados de Huesca y Lérida en el siglo XI I»:Estudios de la Edad Media en la Corona de Aragón 2 (1946) $187-240$. 
not altogether clear. While Muslim raids along the Catalan coast may well have led to Peter II of Aragon's call to Innocent for support, it is probable that it was a war both Peter and the Castilian king wished to start ${ }^{68}$. But what is clear is that, on 16 February 1210, Innocent responded to Peter $\Pi$ 's crusading enthusiasm with Exemplo Miserabilis to Archbishop Rodrigo and his suffragans. From the outset of the campaign we find evident Innocent's view of victory in Spain as essential for success in the Holy Land and his immense caution after so many crusading disasters, as well as the persuasiva powersof a mature politician. As the Christian people have suffered a loss in the Holy Land of Christ, wrote lnnocent ( ever mindful of Hattin ), now you must stand against the trickery of the pagans, at the time when it is fitting and expediente not allowing our Holy Land also to be profaned with the filth of their pollution. Since King Peter, ortodoxa fidei zelo succensus, was prepared to fight, the archbishop is to persuade Alfonso to emulate this pious proposal pro Christi nomine and undertake this task with similar devotion at the opportune time. If Alfonso would not go himself he should at least not impede his subjects who would receive a full remission of sins in promoting tantum Dei servitium ${ }^{69}$.

No doubt Rodrigo did not address Alfonso VIII, the humiliated of Alarcos, in quite that goading manner, but the involvement of Castile was secure, and having received indication of the young Prince Ferdinand's desire to dedicate the first fruits of his military life to Almighty God, in Significavit nobis of 10 December 1210 to the archbishops and bishops of Spain, Innocent sought the unity or neutrality of the other kings and their subjects, who were not strictly tied by truces to the Saracens, to aid the first-bom son of Castile in exterminating the enemies of the name of Christ from the borders of His inheritance which they impiously occupied, for which work the Christian rulers would receive a full remission of sins and merit the glory of heaven, as would those who proceeded out of devotion from whatever country ${ }^{70}$.

While in Cum personam tuam of 22 February 1211, Innocent rejected Alfonso's 'request for a legate to Spain because of the restlessness of the times (tempora impacata), and also probably given Alfonso's much criticised previous crusading track-record the Pope was doubtful of the success of the enterprise, nevertheless he promised he would satisfy the King's request at a

\footnotetext{
68 Above n. 20 and J. Ventura, Pere el Católici Símó de Montfort, Barcelona 1960, 138.

$69 \mathrm{MDHT}$, no. 416, p. 436; M. MACCARRONE, «Orvieto e la Predicazione della Crociata»: in his Studi su Innocenzo III, Padua 1972, 94.

$70 \mathrm{MDHI}$, nо. 442, pp. 472-3; Pothast, 4142; MPL, 216, 353; HuICI MIRANDA, Las Grandes Batallas, 228; RosCHER, Papst Innocenz $I I '$ und die Kreuzzüge, 181. Perhaps the letter was carried from Rome by a Trinitarian as they recelved a privilege confirming their spiralling fortunes at Burgos on 18/12/1210 (Documentación del Monasterio de la Trinidad de Burgos (1198-1400), ed. L. GARCIA ARAGón, Burgos 1985, no. 9, pp. 17-8).
}

Proyección internacional de la iglesia hispana Hispania Sacra 51 (1999) 
more opportune time and reassured that if any king of Spain who had a peace with the King of Castile presumed to violate it while Alfonso was on campaign, he should suffer the ecclesiastical punishments consequent of such an action $^{71}$. Moreover, in Cum donationes of 12 April 1211, recognizing the ever present financiar troubles of the King of Aragon. Innocent revoked many donations that Peter had made before he reached his majority, since he considered it fitting to do so when considering the seriousness and expense with which Peter undertook the battle with the enemies of the Christian name, providing, of course, that Peter did not revoke donations he had made to the Church without an ecclesiastical judgement on the matter ${ }^{72}$.

In Quoad peticiones of 1 June 1211, Innocent forestalled Rodrigo's attempt to tie the primacy issue into the crusade. Rodrigo had hoped to gain a further confirmation of his privileges by using his most definitely important part in the organization and preaching of the -crusade to reconfirm the status of his see. In return Innocent accused the archbishop of a terrible lack of foresight; with the invasion of the Saracens now grave danger threatened Spain and this was hardly a fitting time to sustain a scandal in Spain concerning the primacy. Cum accepero tempus, ego iustitiam iudicabo, quoted Innocent from Psalm 74, stealing the moral highground ${ }^{73}$.

In Recepimus litteras dolore of 31 January 1212, Innocent intemationalized the crusade, calling upon the bishops of France and Provence to preach it to their people. Letters full of sadness and fear had reached Innocent from King Alfonso of Castile, since the Saracens had entered into Spain in vast numbers, and had besieged and occupied a castle of the Cistercian order called Salvatierra. Alfonso, fearing that the danger would increase if he did not act now, called for a campaign commencing in the Octave of Pentecost next, electing to die rather than see harm done to the Christian people Therefore Innocent ordered the prelates to exhort their people, granting them a remission of sins if they would aid Alfonso both with men and money. By doing this both bishops and people would merit eternal glory ${ }^{74}$.

${ }^{71}$ MDHI, no. 447, pp. 475-6; Potthast, 4185; MPL, 216, 353; LINEHAN, History and the Historians, 319; HUICI MiRANDA, Las Grandes Batallas, 229; ROSCHER, Papst Innocenz III. und die Kreuzzïge, 181.

$72 M D H 1$, no. 453, p. 481; Potthast, 4220; MPL, 216, 404; G. CIROT (Ed.), «Chronique latine», 354; T. N. BISSON, Fiscal Accounts of Catalonia under the Early Count-Kings (1151-1213), 2 vols, University of California 1984, 1, 130.

${ }^{73}$ MDHI, no. 455, pp. 482-3; Potthast, 4258; MPL, 216, 423; LINEHAN, History and the Historians, 328 n. 49.

$74 M D H I$, no. 468, pp. 497-8; Potthast, 4373; MPL, 216, 514; $D R H$, Bk. VI I, c. 35, p. 253; LUCAS OF TúY, Crónica de España, 413; Primera Crónica General, c. 1008, p. 686; GoÑ GAZTAMBIDE, Historia de la bula, 113; HUICI MIRANDA, Las Grandes Batallas, 229; L. SUÁREZ 
In Cum personam tuam of 4 February 1212, having sent his condolences to Alfonso for the death of Prince Ferdinand (in Madrid in October 1211), and having informed Alfonso that he had initiated the preaching in France, Innocent developed one of his main crusading themes, that the humility of the Christian before God would eventually triumph over the arrogance and evil pride of the infidel. 'Place your hope in the Lord your God', he addresses Alfonso, 'and humble yourself before $\mathrm{Him}$ who gives grace to the humble, and returns retribution to the arrogant; it is through the power that God gives to you, that you will magnificently triumph over the enemies of the Cross of Christ'. Despite this, considering the possible effect on morale of the loss of Ferdinand, and recognizing that apart from the King of Aragon, the support or even neutrality of the other kings was not secure, and seeing that war in the Midi, conflict in Germany, and interdict in England made outside support seem unlikely, Innocent offered Alfonso the option of saving face and negotiating a truce ${ }^{75}$.

Alfonso, however, was now determined to go ahead and in Quanta nunc necessitas of 5 April 1212, to Rodrigo and Archbishop Peter of Compostela, Innocent made one final effort to secure peace. How great a danger now threatened Spain was best known to them and therefore they should persuade the kings of Spain to serve a peace and truce, especially during the imminent danger of the Saracen wars. If anybody (and here Innocent specifically ment ions Alfonso IX of León), should help in any way the enemies of the Cross of the Lord, who not only aspired to the destruction of Spain but also to other lands of the Faithful of Christ, they were to be subject to excommunication and their lands placed under interdicto. Moreover, if there were quarrels between the kingdoms, because of the immediate danger these were to be deferred to a more suitable time, and the royal procurators could then argue out their differences at the Papal Court, and Innocent would hear the cases personally ${ }^{76}$.

Innocent's final contribution prior to the battle was the Supplicatio Generalis, the call for a general procession in Rome on 22 May 1216, the Wednesday after Pentecost, the time originally set for the beginning of the Las Navas campaign and the time at which the Pope presumed the campaign was taking

\footnotetext{
FERNÁNDEZ, Historia de España, Madrid 1970, 268m9; L. G. DE VAldEAvellano, Historia de España: De los origines a la baja Edad Media, 2 vols, Madrid 1973, 2, 600.

${ }^{75}$ MDHI, no. 470, pp. 500-1; Potthast, 4375; MPL, 216, 513; DRH, Bk. VII, c. 36, pp. 257-8; G. CIROT (Ed.), «Chronique latine», 273; Los Anales Toledanos, 177; Primera Crónica General, c. 1009, p. 687; 'Annales Compostellaní, ed. E. FLóREZ and M. RISCO, España Sagrada, 51 vols, Madrid 1747-1879, 23, 323; HUICI MIRANDA, Las Grandes Batallas, 229; ROSCHER, Papst Innocenz III und die Kreuzzz̈̈e, 182.

${ }^{76}$ MDHI, no. 471, pp. 501-2; Potthast, 44I7; MPL, 216, 553; HUICl MIRANDA, Las Grandes Batallas, 229-30; ROSCHER, Papst Innocenz III und die Kreuzzüge, 183.
}

Proyección internacional de la iglesia hispana Hispania Sacra 51 (1999) 
place $^{77}$. Here more clearly than ever before we can witness the fusion of the ideology of the crusade with the movement of lay piety, with the call for vita apostolica, and it is here, prior to the Fifth Crusade, and also, as Dickson has recently written, significantly influencing the Children's crusade ${ }^{78}$, that Innocent uses those liturgical skills that he had leamt before all else, to draw the Christian community into a mystical union that transcended tradicional political and ethnic considerations.

The procession was called for the peace of the Universal Church and the Christian people (pro pace universales ecclesie ac populi Christiani), especially so that God might be favourable in the war that was now supposed to be taking place between the Christians and the Saracens in Spain, lest the Lord should give his people up to mockery, and allow other nations to rule over them. There were to be three groups in the procession, essentially men, women, and clergymen, all proceeding in prayer with devotion and humility and all going barefoot, each group taking a different route, but all meeting at the same place, the Lateran campus. Meanwhile, Innocent, with the Cardinal bishops and the papal chaplains, was to enter the chapel which is called the Sancta Sanctorum, and from there they were to process with a relic of the True Cross, to the palace of the cardinal bishop of Albano, in front of which Innocent was to preach a sermon to all the people. Later the Pope, clerics and laymen were to return to the Lateran basilica for the celebration of Mass before all who were able were to return home to undertake a severe bread and water fast. Through prayer, fasting, and almsgiving, Innocent insisted, the compassion of the Creator would be returned to the Christian people ${ }^{79}$.

\section{The Significance of Las Navas to INNOCENT III}

If, as tradition has it, the bones of the Cid rattled in their tomb on the eve of Las Navas ${ }^{80}$, then we might say that the ghost of Celestine III would have breathed a sigh of relief on the evening of 16 July. The Christians had won, spectacularly, and Innocent III had been proved right. We do not know when he received the news, but it was by mid-October and probably well before. Innocent read out to the Roman people Alfonso VIII's famous account of Las Navas and the taking of ubeda, and explained it to them in the vernacular. All

${ }^{77} M D H I$, no. 473, pp. 503-4; Potthast, 4417; MPL, 216, 553.

${ }^{78}$ G. DICKSON. «La Genése de la croisade des Enfants (1212)»: Bibliothèque de l'école des Chartres, $153(1995) 82$.

${ }^{79} M D H I$, no. 473, pp. 503-4; Potthast, 4417; MPL, 216, 553.

${ }^{80}$ MÉNENDEZ PidAl, La España del Cid (cit. n. 34), 463.

Proyección internacional de la iglesia hispana Hispania Sacra 51 (1999) 
gave thanks that God had given Alfonso the strength and virtue to restore the miracles of the Old Testament. Rather than being, as Roscher maintained, of little importante to Innocent, Innocent saw in the success of Las Navas a sure sign of Divine intervention in the World. God had shown His compassion upon Alfonso and upon the Christian people and poured out his anger on the races that did not know the Lord, and the kingdoms that did not know his name, humbling the strength of the arrogant and giving strength to those who trusted in the Lord 'Dominus virtutem populo suo dabit', reflected Innocent reminding Alfonso that God and not he had won the battle ${ }^{81}$. Innocent was now convinced that the heretics who poisoned the Church were about to be destroyed. He threatened the heretical Milanese, in a tone that was, as Webb put it, 'both minatory and exultant', that crusading victorias in Provence and Spain showed a multitude of armies could not destroy the Lord ${ }^{82}$. Moreover, the optimism generated by the victory developed in Innocent's mind the idea of a total liberation of the Holy Land. In Quia malor, the call to the Fifth Crusade of April 1213, in referente to Las Navas, Innocent said 'God has now given us this good sign that the end of the beast is approaching' ${ }^{\prime 3}$. As Lomax demonstrated, Iberia now receded in its importante to Christendom ${ }^{84}$, though Innocent left open the option of organizing the war against the Moors if circumstances required ${ }^{85}$.

\section{The French and Las Navas}

One of the most significant contributions Innocent had attempted to make to Las Navas was in his efforts to internationalize the crusade. By Alfonso VIII's estimate about 62,000 and by Arnaud Amalric's about 40,000 French

${ }^{81}$ MDHI, no, 488, pp. 519-21; Potthast, 4613; MPL, 216, 703; MACCARroNe, "Orvieto e la Predicazione»(cit. n. 64), 98-99, cf. AMALRIC, De Franconum Expeditione, RHGF 19 (cit. n. 29), 253; 'Benedictus per onnia Dominus Jesus-Christus, qui per suam misericordiam in nostris remporibus, sub felici apostolatu domini Papae Innocentii, de tribus pestilentium hominum et inimicorum ecclesiae sanctae suae, videlicet orientalibus schismaticis, occidentalibus haereticis, meridionalibus Sarracenis, victorias contulit Catholicis Christianis'.

82 Potthast, 4611; MPL, 216, 710-4; D. WEBB, «The Pope and the Cities: Anticlericalism and Heresy in Innocent III's Italy»: Studies in Church History, subsidia 9 (1991) 150.

${ }^{83}$ Potthast, 4725; MPL, 216. 817: MACCARRONE. «Orvieto e la Predicazione», 100-1.

84 D. LOMAX, «La conquista de Andalucía a través de la historiografía europea de la época»: E. CABRERA (Ed.), Andalucia entre Oriente y Occidente (1236-1492). Actas del V Coloquio Internacional de historia medieval de Andalucía, Cordoba 1988, 3749.

85 J. POWELL, Anatomy of a Crusade 1213-1221, University of Pennsylvania 1986, 21, 31 n. 18; LINEHAN, Spanish Church (cit. n. 6), 6; GOÑ GAZTAMBIDE, Historia de la Bula (bit. n. 22 ), 133.

Proyeccion internacional de la iglesia hispana

Hispania Sacra 51 (1999) 
soldiers came to the crusade ${ }^{86}$. Arnaud Amalric, Lucas of Tuy, Alfonso VIII, the Annals of Toledo, the Primera crónica general, were all agreed that these knights had come because of the indulgences granted by the Pope ${ }^{87}$. Unfortunately, only Arnaud Amalric and about 130 of these men took part in the battle ${ }^{88}$. The exact reasons and circumstances in which the ultramontano crusaders departed may never be absolutely clear. Arnaud Amalric would have been in the best position to inform us (and everybody else since it was his victory letter to the Cistercian General Chapter which spread news of Las Navas throughout the Occident) but regrettably, though understandably, he opted for an embarassed silence ${ }^{89}$. The Spanish eagerness to paint the French knights as cowardly and treacherous, and thus finally to put paid to all that nonsense about Charlemagne and all those ghastly chansons, does not altogether help ${ }^{90}$. Certainly the terrain was diffcult and it was somewhat hot, as Alfonso VIII wrote to Innocent, tongue in cheek ${ }^{91}$. But that is not enough in itself. One might reflect that for that same July 1212; Pierre Vaux-de-Cernay describes how, on the road to Carcassonne with Lady de Montfort, many of his companions fainted because of the violent heat of the summer and the difficulty of the route - yet few would suggest the Albigensian crusaders lacked mettle $e^{92}$. Certainly the very different actitudes of the French and the Iberian forces on how to behave towards the Muslims (the former opting for slaughter, tended to see compromise as treachery and the latter $f$ inding negotiation with the enemy much easier than with their allies) $)^{93}$ and the lack of provisions played a great

$86 \mathrm{MDH}$, no. 483, p. 510; AMALRIC, De Francorum Expeditione, 251; on the numbers in the battle, M. ALVIRA CABRER, «La muerte del enemigo en el pleno medievo: cifras e ideología (El modelo de Las Navas de Tolosa)»: Hispania 55 (1995) 403-423.

87 AMALRIC, De Francorum Expeditione, 250-1; LuCAS of TUY, Crónica de España, 413; MDHI, no. 483, p. 510; Primera Cronica General, p. 692, c. 1013; Los Anales Toledanos, 172.

${ }^{88}$ DRH, Bk. VII, c. 6, pp. 265-6; cf. The Poem of the Cid, trans R. HAMILTON and J. PERRY, London 1984, 110-1, where Minaya asks for 130 knights from the Cid to attack the Moors on the flank. Alfonso VIII in MDHI, no. 483, p. 511, has 150 French knights remaining.

${ }^{89}$ LOMAX, «La conquista de Andalucía» (cit. n. 84), 38; M. ALVIRA CABRER, «El Venerable Amaldo Amalarico (h. 1196-1225); idea y realidad de un Cisterciense entre dos cruzadas»: Hispania Sacra 48 (1996) 580-1.

90 DRH, BK.IV, c. 11, pp. 128-30; Los Anales Toledanos, 172; BARKAI, Cristianos y Musulmanes (cit. n. 17), 217-8.

${ }^{91} M D H I$, no. 483, p. 511 ; G. CIROT (Ed. ), «Chronique latine», 356; LINEHAN, «Religion, nationalism and national identity» (cit. n. 17), 192.

92 PIERRE DES VauX-DE-CernNaY, Histoire Albigeoise, trans. P. GUEBIN and H. MAISSONNEUVE, Paris 1951 , c. 339 , p. 133.

93 HuICI MIRANDA, Las Grandes Batallas, 246; DefourneauX, Les Français en Espagne (cit. n. 17), 190; R. S. LOPEZ, «Fulfilment and Diversion in the Eight Crusades Outremer, Jerusalem 1982, 18. B. KEDAR, H. MAYER, R. SMAIL (Eds), Outremer, Jerusalem 1982, 18. 
part in the abandonment ${ }^{94}$, but one should also consider that the French knights might have been slightly uncertain as to the purpose of the campaign, since Innocent and more so the Cistercian information network had preached the crusade very much more in terms of the loss of Salvatierra, from 1198 the major fortress of Calatrava, which was affiliated to Citeaux ${ }^{95}$. We might not suspect this if Alfonso in his victory letter to Innocent had not been so insistent that the French knew that there was going to be a battle ${ }^{96}$, and if Sancho VII, in the Navarrese account that reached his sister Blanche, had not maintained that at one point Alfonso VIII had tried to turn the Crusade upon Alfonso IX ${ }^{97}$. That was Navarrese propaganda, and Sancho VII only arrived after the French departed, but it is not too unlikely that it was the sort of rumour that was already circulating in the camp. Moreover, one must consider that papal action in the South of France, the papal humiliation of John, and the papally inspired conflict in Germany, meant there were attractions above home-cooking that motivated their departure.

\section{THE PAPACY AND SPAIN}

The greatest success and surprise for Innocent was that Arnaud Amalric, whose Languedocien legation had been extended in June 1210 to include the diocese of Pamplona ${ }^{98}$, managed to persuade Sancho VI I of Navarre to join the kings of Castile and Aragon on the battlefield, despite long-held grudges and a prior assurance by Sancho that he would not come ${ }^{99}$. The Muslims considered that the Roman 'Emir' had threatened to turn all the Christian forces

94 MDHI, no. 483, p. 511; DRH, Bk. VII1, c. 6, pp. 265-6; Primera Crónica General, c. 1016, p. 697; DefourneauX, Les Français en Espagne, 190; GoÑ GAZTAMBIDE, Historia de la Bula, 122; HUICI MIRANDA, Las Grandes Batallas, 244.

95 LOMAX, La Reconquista (cit. n. 34), 162; FOREY, «The Military Orders and the Spanish Reconquest «(cit. n. 22), 212-3; DEFOURNEAUX, Les Frangais en Espagne, I82; J. F. O'CALLAGHAN, «Sobre los origines de Calatrava la nueva»: Hispania 23 (1963) 498-9.

$96 \mathrm{MDHI}$, no. 483 , p. 511.

${ }^{97}$ Letter of Queen Blanche to Blanche, in RHGF 19 (cit. n. 29), 255-6; cf. GOÑ GAZTAMBIDE, Historia de la Bula, p. 124.

98 Pothast 4027; ALVIRA CABRER, «El Venerable Amaldo Amalarico», 572; R. FOREVILLE, Le Pape Innocent III et La France, Stuttgart 1992, 235-6; IDEM, «Anaud Amalric, archevêque de Narbonne (1196-1225)»: Narbonne, Archéologie et histoire. Fédération historique du Languedoc méditerranéen et du Rousillon, Montpellier 1973, 131-2.

99 De Franconm Expeditione, 25I; DRH, Bk. VIII, c. 6, p. 266; LACARRA, Historia del Reino de Navarra (cit. n. 63), 233; cf. CARLOS, PRINCIPE DE VIANA, Crónica de los Reyes de Navarra (cit. n. 9), 111115; La Chanson de la Croisade Albigeoise, ed. E. MARTLN-CHABOT, 2 vols, Paris 1931, 1, p. 18.

Proyección internacional de la iglesia hispana Hispania Sacra 51 (1999) 
upon Sancho if he did not break his alliance with them ${ }^{100}$. Be that as it may, Innocent could not achieve a perfect quintet - war between Portugal and León in 1212, and the all too beautiful opportunity for Alfonso IX if Castile lost, saw to that; but crucially neither kingdom sided with the Moor and both did send knights to the battle ${ }^{101}$. In the interests of the Christian Faith, the Papacy had helped to achieve a solidarity hitherto unknown. Though the Kings of León and Portugal could not make it at the time, they had arrived at the battle within a generation and have been there on and off ever since ${ }^{102}$. That is importante For Spain, Las Navas was to represent the profound unity of the Spanish kingdoms, the essential epoch-breaking act of Spanishness, a myth of union, more important than the battle itself, and a myth in which the Papacy could necessarily play no part. But that the myth existed from the time and in the $f$ orm that it did owed no little amount to Innocent III and his predecessors. The Cyprianic-Augustinian concern with the Unity of the Church and with Peter as symbol of that union, so important in Innocent's pontificate ${ }^{103}$, had been transporte into a Spanish context, and at least in this sense we might say that Spain was made, as much as Spain ever was to be made, by and not in opposition to North Africa. 240.

${ }^{100}$ Colección de Crónicas Árabes (cit. n. 20), 2, 271; Hulci MIRANDA, Las Grandes Batallas,

${ }^{101} D R H$, BK. VIII, c. 2, p. 260; LUCAS OF TúY, Crónica de España, 4l3-4; Primera Crónica General, c. 1011, p. 690; GoNZÁLEZ, Alfonso VII, 1, 1010; IDEM, Alfonso IX, 1, 144-6.

102 Los Anales Toledanos, 172; GONZALEZ, Alfonso VIII. 1, 1056-7; LINEHAN, History and the Historians, 297, notes the change though pointing out that the DRH and the Primera Cronica General keep Alfonso IX of León firmly absent. B. REILLY, The Medieval Spains, Cambridge 1993, 136, in a rare oversight, implicitly casts the kings of Portugal and León as 'principals among the victors'.

${ }^{103}$ K. FroELICH, «Saint Peter, Papal Primacy, and the Exegetical Tradition, 1150-1300»: C. RYAN (Ed.), The Religious Roles of the Papacy: Ideals and Realities 1150-1300, Toronto 1989, 17.

Proyección intemacional de la jglesia hispana Hispania Sacra 51 (1999) 